CAE Working Paper \#03-06

The Global Child Labor Problem:

What Do We Know and What Can We Do?

by

\author{
Kaushik Basu \\ \& \\ Zafiris Tzannatos
}

June 2003 
May 6, 2003

\title{
The Global Child Labor Problem: What Do We Know And What Can We Do?
}

\author{
Kaushik Basu and Zafiris Tzannatos
}

\begin{abstract}
The problem of child labor has gone beyond being viewed as a matter of regional and intra-national concern to one of international debate and possible global 'persuasion' and policy intervention. It is argued in this paper that, in crafting policy for mitigating this enormous problem of our times, it is important to acquire a proper theoretical and empirical understanding of the phenomenon. What gives rise to child labor and what are its consequences? What are the interventions that we can think of in order to end child labor without hurting children? A well-meaning but poorly designed policy can exacerbate the poverty that these laboring children face and even bring them to starvation. The present paper surveys the large and rapidly growing literature on this subject, focusing mainly on the new literature that uses the best of modern economic theory and econometrics. We then go on to discuss some of the broad policy implications of these new findings and hope that this will contribute to better-informed discussion and policy design in this area.
\end{abstract}

JEL classification numbers: J00, O10, I30

Key words: child labor, international labor standards, education, human capital

Acknowledgements: In writing this survey we have learned a lot from a conference on child labor that was organized in Oslo, 28-29 May, 2002, through the auspices of FAFO, UNICEF and the World Bank. We would like to thank Francois Bourguignon, Bjorne Grimsrud and Furio Rosati for having made this conference possible, and to Sonia Bhalotra, Eric Edmonds and Gayatri Koolwal many helpful comments. Finally we have benefited greatly from the suggestions and criticisms that we received from three anonymous referees and Francois Bourguignon. 


\section{The Global Child Labor Problem: What Do We Know And What Can We Do?}

\section{Introduction}

From at least as far back as 1802, when Robert Peel's Factories Act was passed in Britain, there has been serious effort to root out child labor. In these two hundred years the world has seen economic growth and the rise of prosperity that, even till fairly recently, would have been beyond the human imagination. If, despite that, today, at the time of celebrating the second centenary of the Factories Act of 1802, the world has an estimated 186 million child laborers ${ }^{1}$, this is a failure of stunning proportions.

The activism and economic progress of the nineteenth and early twentieth century saw some sharp reductions in child labor in industrialized nations. What may not have been realized then was that some of this problem had merely been exported to the developing countries, which already had their own child labor problem. Partly thanks to the difficulty of collecting data on child labor, and partly because most child labor is integrated with other family work, its dimensions remained unknown for a long time. Then, as recently as the nineties, and following the Convention of the Rights of the Child (1989), a confluence of factors, such as globalization, increased awareness of what is happening in distant countries and the collection of systematic statistics by the ILO, the World Bank and individual nations, the world became aware that from a global point of view the situation in many countries was not much better than during the industrial revolution, that large numbers of children have been working shockingly long hours in

\footnotetext{
${ }^{1}$ This pertains to the year 2000, the latest for which global data are available (ILO, 2002). A more detailed discussion of these statistics occurs in section 3. But it is worth
} 
factories and sheds that are frequently ill-lit, squalid and a hazard to workers' health. One concomitant of this has been an outpouring of writing, research and concern regarding child labor over the last decade or so. Recent research has given us an understanding of the phenomenon and the consequences of alternative policy interventions that earlier governments and international organizations did not have access to. This raises hope that one can conceive of a time-bound plan for putting an end to child labor and raising the level of well-being of children the world over.

The aim of this paper is to pull together the recent research and help think about policy to deal urgently with this unnecessary problem of our times.

\section{Theory}

\subsection{Basic Model}

In this and the next two sections we review some of the theory that underlies the empirical investigations and some of the assumptions that, in turn, underlie the theory. Two crucial assumptions that were used in some of the early models (see, for instance, Basu and Van, 1998; Swinnerton and Rogers, 1999) and have been subsequently used in a wide range of analyses, from dynamics to the modeling of social norms are the socalled 'luxury axiom' and 'substitution axiom'.

The luxury axiom asserts that households send their children to work only when driven to do so by poverty. In other words, child non-work (which would, typically, consist of schooling and leisure) is a luxury good: Households whose non-child labor incomes (or, in brief, adult incomes) are very low cannot afford to indulge in keeping children out of some productive activity. It is only when adult incomes begin to rise that

mentioning here that of all children, up to age 17, 5.7 million are in forced and bonded 
households take children out of the labor force. Implicit in this assumption is an altruistic view of the household: parents or guardians do not like to make their children work unless compelled by circumstances. The evidence seems to us to largely confirm this axiom (Edmonds, 2001; Admassie, 2002; Wahba, 2002; Grootaert and Patrinos, 2002; see also the papers in Grootaert and Patrinos, 1999), though of course there will be exceptions, or what looks like exceptions, and we turn to some of these in a later section.

The substitution axiom asserts that adult and child labor are substitutes, subject to some adult equivalency correction. More specifically, it means that adults can do what children do. There used to be a certain presumption in the folk literature on the subject that there were certain tasks specific to children. Expressions like 'nimble fingers' to describe child labor tended to perpetuate this belief. The substitution axiom expresses a contrary view on this. And a careful study of the technology of production involving children by Levison et al (1998) lends strong support to the substitution axiom. They show that adults in India are as good if not better in producing hand-knotted carpets as children. So from a purely technical point of view it is possible to replace child labor with adults. But of course adults cost more and for that reason firms may be reluctant to make the transition to adults-only labor.

The basic idea behind the theory that emerges from these axioms is simple. Suppose, for simplicity that the economy consists of $\mathrm{N}$ households and each household consists of one adult and $\mathrm{m}$ children. Production takes place using labor alone. By doing a full day's work each adult can supply one unit of labor and each child $\gamma(\# 1)$. This assumption formalizes the substitution axiom for our use. Child labor is a substitute for 
adult labor, subject to an equivalent scale correction. Let the wage rate for a full day's work by an adult be w and the wage rate for a full day's work by a child be $\mathrm{w}^{\mathrm{c}}$. Clearly $\mathrm{w}^{\mathrm{c}}=(\mathrm{w}$.

Each household decides what is the minimum, tolerable level of consumption for the household. We shall call this 'subsistence consumption' and denote it by s, though this may well embody 'social' notions of what is considered an acceptable level of consumption. Adults work full time. If an adult finds that by working full time, income falls short of the subsistence consumption, then and only then are children sent to work (the luxury axiom). Now consider Figure 1, where adult wage is represented on the vertical axis. If this wage is greater than s, then only adults supply their labor. Assuming, for simplicity that adult labor supply is perfectly inelastic, we have AB as part of the labor supply. As w drops below s, children are sent out to work in an effort to reach the target acceptable level of income. Hence, as w keeps dropping further below s, total labor supply keeps increasing. This continues till there is no further labor to supply. Then labor supply becomes inelastic once again. This explains the shape of the supply curve ABCF.

The essential feature of the supply curve here is its backward bending section. Beyond this we can get many variations under different assumptions. The stretch BC can be a segment of the rectangular hyperbola under the assumption that the household uses child labor exactly so as to achieve a total income of s. This however may not be reasonable if it is the case that a small amount of child labor makes it impossible to go to school. Then once a child is made to work the household may decide to make the child work quite a bit, thereby making the $\mathrm{BC}$ segment more elastic. But as long as we have the 
backward bending segment, the possibility of the demand curve for labor intersecting the supply curve more than once is a reality ${ }^{2}$.

Such a possibility with a standard downward sloping demand curve for labor is illustrated in figure 1 . In this case the labor market has three equilibria, $\mathrm{E}^{1}, \mathrm{E}^{2}$, and $\mathrm{E}^{3}$. Of these, $E^{1}$ and $E^{2}$ are stable and we shall focus on these. At $E^{1}$ wages are high and there is no child labor, while at $\mathrm{E}^{2}$ wages are low and a high incidence of child labor. The same economy can get caught in any of these equilibria ${ }^{3}$. If such an economy is stuck at the 'bad equilibrium', that is, one with high child labor, it pays to have a legal intervention banning child labor, for this will deflect the economy to the 'good equilibrium'.

It should be stressed that this does not automatically amount to a case for legal intervention, whenever we see child labor. In a very poor economy, it is entirely possible that the demand for labor is so low that the only intersection of the demand curve with the supply curve occurs on the segment CF. In that case a ban on child labor can backfire, leaving the children and their parents impoverished and even risking starvation.

In the above model, child labor is driven by poverty. This is not to deny that it can have other causes, some even beyond economics. There are important writings, notably

\footnotetext{
${ }^{2}$ How plausible is this multiple equilibria in reality? It is arguable that in many nations, such as India or China, where child labor as a percentage of adult labor is so small that a ban on that is unlikely to raise adult wage sufficiently so as to make parents voluntarily withdraw their children from the labor force. While this may indeed be so with India or China, there are several nations, such as Ethiopia or Nepal, where child labor as a percentage of adult labor is much higher (around 4 times that of India or China). In such countries the effect on adult wage of a ban on child labor may not be negligible. Moreover, in reality one household does not look like another household and likewise for firms. Once we recognize this, it becomes evident that the multiple equilibrium result will not obtain as cleanly in reality as in our model where all households are identical. But on the other hand, this makes us realize that if we consider child labor as a percentage of the totally unskilled adult labor (which is what child labor competes with) this ratio will be higher than child labor as a percentage of adult labor. Hence, a ban on child labor can have a fairly substantial effect on the wage rate of totally unskilled workers. In other words there may be a segment of the heterogeneous economy where the effect is large.

${ }^{3}$ A different kind of coordination problem and multiple equilibria is explored in Dessy and Pallage (2001). In their work the failure of coordination is between parents' decision about child education and the decision
} 
by Zelizer (1985), which point to the changing 'social conception' of childhood and, relatedly, the value of the child. ${ }^{4}$ How important are these social factors in explaining child labor? Zelizer is right in asserting that, in the nineteenth-century (shocking though this may seem to us today), child labor was often commended as necessary for building character and discipline, and valuable for industrial competition. However, one must be cautious in not interpreting every opposition to legislation banning child labor as reflecting such views and supporting child labor. Even in contemporary times many economists oppose coercive legislation (in some contexts, so do we), but this usually reflects their view of how the labor market works and how legislation is likely to affect children; it need not be an indicator of any normative difference or difference in the conception of childhood and the worth of children.

What one can take away from Zelizer is that social norms matter and these can be in very concrete ways, as demonstrated by Lopez-Calva (2003), following the models of Lindbeck, Nyberg and Weibull (1999). In a nutshell the argument is as follows. For simplicity, assume that each household $\mathrm{i}$ has one child and child wage-rate is fixed at $\mathrm{w}^{\mathrm{c}}$. The benefit from having the child work is given $b \mathrm{w}^{\mathrm{c}}$. To decide whether child labor is worth it, from the benefit one must deduct the cost of having the child work. Let c(i) be the leisure cost of child work as perceived by household i. Without loss of generality, assume that c(i) rises monotonically with i. But suppose there is another cost of sending the child to work, namely, the social cost or the cost of stigma, ( . Following standard arguments, for instance, Granovetter and Soong (1983), we shall assume that this cost

of firms to adopt a suitable technology. In their model, unlike in ours (see Basu, 2002), the equilibria are Pareto ranked.

${ }^{4}$ Indeed there persuasive historical accounts of how child labor was often valued and technology that could use child labor was advertised as such (Tuttle, 1999). 
depends on how many others send their children to work. So if it is expected that $\mathrm{n}$ children are working then the stigma cost of sending a child to work is given by ( (n), where (' $(n)<0$, suggesting that one becomes more brazen if more people are doing the same. Hence, household $i$ will send its child to work if and only if $w^{c}-($ (n) \$ c(i). Now define $4(n)$ as the critical household that will send its child to work when it is expected that $\mathrm{n}$ children are working in the aggregate. Hence, $\mathrm{w}^{\mathrm{c}}-((\mathrm{n}) / \mathrm{c}(4(\mathrm{n}))$. Since, when $\mathrm{n}$ is the expected size of aggregate child labor, all households i \#4(n) will send their children to work, it follows that the actual amount of child labor will be equal to $4(n)$. Evidently, $\mathrm{n}^{*}$ is an equilibrium amount of child labor (in the sense of rational expectations) if $\mathrm{n}^{*}=$ $4\left(n^{*}\right)$. Hence, child labor can depend critically on social norms, in particular on the stigma costs of sending a child to work. It is also easy to see that the function $4(n)$ is a monotonically increasing function. Hence, social norms can be compatible multiple equilibria. Two innately identical societies can socially engineer themselves into different levels of child labor, which, once in place, tend to persist. Also, given that social stigma may vary depending on whether a child works in a factory, farm or at home, the basis and extent of different kinds of child labor may vary between urban and rural areas and between factories and homes.

It is possible to go beyond poverty and social stigma and look for yet more causes of child labor. Child labor could depend on the quality and availability of schools and the transactions cost of child work. These variables can, in turn, be further disaggregated. Moreover, there is evidence that some of these variables affect fertility (Tzannatos and Symons, 1989), which would make m endogenous. Relatedly, the incidence of child labor will respond to incentives given by government to make schooling more attractive, such 
as giving children food for attending school, or giving parents of school-going children incentives such as cash transfers.

The relation between child labor and schooling can be captured theoretically in a somewhat different way by a political economy model. Such models are quite new in this area and their full implications remain to be evaluated. But a brief account of such a model is provided in the next sub-section.

\subsection{Child Labor, Schooling and Political Economy}

Political economy models in this area are, as yet, rare (Krueger and Tjornhom, 2001; Doepke and Zilibotti, 2002; Tanaka, 2003). These models give us some nice insights into child labor and schooling, and endogenously explain why some nations ban child labor and others do not.

In Tanaka's model government does not legislate against child labor. Instead, it collects taxes and runs schools and, by making the schools sufficiently good, tries to wean children away from labor to education. Hence, in this model, as the tax rate is raised, as long as a household does not send its children to school, it is worse off; but once it decides that the schools are good enough to take the children out of the labor market and send them to school, its welfare responds to the tax rate like an inverted-U, since an increase in the tax rate improves the quality of schools. Households differ from one another but their broad contour of preference is as just described. This means that preferences are not single-peaked but they are nevertheless of the kind that may satisfy the conditions for the use of the median voter theorem (Epple and Romano, 1996; Glomm and Romano, 1998). Tanaka then imposes the necessary technical restrictions and uses the median voter theorem to predict the tax rate (and therefore the quality of 
schooling) that the government will choose. This in turn determines the incidence of child labor that occurs in the economy. In his model a rise in the tax rate results in a decline in child labor. But in the end the tax rate itself is deterministic. He shows that, if inequality is high, in the sense of the median income being much lower than the average income, then the tax rate will be low and child labor will be high. Like in the model of Swinnerton and Rogers (1999), inequality is closely related to the incidence of child labor, though the causation is very different.

In an elegant model, which they then calibrate to fit Britain's experience in the nineteenth century, Doepke and Zillibotti (2002) endogenize the very act of restricting child labor. In their model, households with many children and less wealth tend to oppose legal restrictions on child labor (for reasons similar to ones investigated above). They however recognize that the number of children that a household has and the amount of human capital that it possesses would, in turn, depend on whether there is a legal ban on child labor or not. They first model the steady state that occurs in the presence of a legal ban and the one that occurs in the absence of it. Interestingly, in the presence of such a restriction the steady state is characterized by greater equality and more social mobility.

The most interesting feature of their model is the part where the restriction itself is endogenously explained. They show that there may be multiple steady-state equilibria in the economy. We can have an economy in which fertility is high, per capita wealth is low and poorly distributed and opposition to legal restrictions so high that government does not legislate against child labor and the above description persists through time. The same economy could alternatively be caught in a steady-state equilibrium where household size is low, equality high and public opinion strongly in favor of a legislative ban. One 
exogenous change that can shift an economy from the former equilibrium to the latter is a rise in the productivity of education.

\subsection{Dynamics, Traps and Other Theoretical Extensions}

In the discussion thus far, barring the last few paragraphs, dynamics received little attention. As soon as we show an interest in this and to what happens to children when they grow up, it becomes essential to, minimally, break up children's activities into three categories: leisure, schooling, and work. This allows us to ask meaningful questions concerning what happens to human capital formation over time and whether child labor helps or hurts in the accumulation of human capital. Also, there are important questions to be asked about the relation between child labor and schooling. If a child's total time is broken up between labor and schooling, a rise in child labor will, by definition, imply a fall in schooling. But bringing in leisure as a separate category allows us to look for more complicated relations between labor and education. Finally, an explicit modeling of schooling permits us to inquire into what happens to child labor over time. There is fortunately, now a small literature that analyzes the dynamics of child labor. ${ }^{5}$

This literature assumes that a person, who receives more education as a child, grows up to have a higher human capital. It is possible to add qualifications to this by noting that child work can at times take the form of apprenticeship, which enables the child to learn some craft or acquire some other form of human capital, or that in acquiring human capital it is not only the amount of time spent on schooling that counts but also the amount of money spent on education. While these are possible, it seems reasonable to assume that there is a positive link between the amount of schooling and human capital

\footnotetext{
${ }^{5}$ Basu (1999), Dessy (2000), Razzaz (2001), Hazan and Berdugo (2002), Emerson and Souza (2002), Bell and Gersbach (2001).
} 
acquired. Now, under normal conditions in capital and labor markets, a higher human capital will mean a higher labor income. Hence, if a child supplies more labor and gets less education as a child, he or she will grow up to be poorer as an adult. Therefore, the kind of logic used in the model in subsection 2.1, would mean that this person, when he becomes an adult, will, in turn, send his or her child to work, thereby perpetuating child labor across generations. Child labor can thus be thought of as a 'dynastic trap'. A child laborer tends to have children who are child laborers by virtue of their dynastic history. Likewise, once a child manages to go to school, which will typically mean escaping labor, it is likely that he or she will have a larger income as an adult and therefore have no need to send his or her progenies to labor.

Hence, there is once again the possibility of multiple equilibria: two otherwise identical dynasties can be such that one is caught in the dynastic child labor trap, whereas in the other nobody works as a child. This gives rise to a host of possible policy interventions, including the provision of loans, bans on child labor and the provision of subsidized schooling or simply information campaigns about the adverse effects of certain types of child labor (this could raise awareness of the parents and urge them to weight more strongly the long-run costs of child labor, which amounts to increasing the benefits of schooling in their perception). The interaction between child labor and the nature of the capital market has been studied in a multi-period model by Baland and Robinson $(2000)^{6}$. They construct an interesting model in which it is Pareto efficient to ban child labor.

\footnotetext{
${ }^{6}$ See also Ranjan (1999) and Cigno, Rosati, and Tzannatos (2002). A cross-country study by Dehejia and Gatti (2001) lends support to the thesis that lack of access to credit contributes to child labor. Households use child labor as an instrument for coping with income variability. On this, see Jacoby and Skoufias, 1997.
} 
It is possible to develop the above sketch of dynamics further by modeling explicitly the household's fertility decision. Hazan and Berdugo (2002), building on the work of Galor and Weil (1996) do this and show how economies can be caught in a trap where fertility is high, as is child labor, and output per capita is low. Technological progress increases the wage differential between adults and children. This lowers the benefit from child labor and leads to a lowering of fertility. In their model, banning child labor hastens the transition process to low fertility and sustained growth steady-state equilibrium, which is Pareto-dominant.

Over the last few years the theoretical analyses of child labor have been extended in various directions, analyzing the formation of social norms and the role of 'tipping points' (Chaudhuri, 1997; Lopez-Calva, 2003), the relation between child labor and trade (Ranjan, 2001; Jafarey and Lahiri, 2002; Brown, 2000; Dixit, 2000; Brown, Deardorff and Stern, 2002), the relation between income distribution and child labor (Swinnerton and Rogers, 1999; Rogers and Swinnerton, 2001), the effect of minimum wage legislation on child labor (Basu, 2000), the worst forms of child labor (Dessy and Pallage, 2002; Arnab Basu and Chau, 2002), efficiency wage and child labor (Genicot, 2000), Nash bargaining and child labor ${ }^{7}$ (Gupta, 2000; Iversen, 2002a), and the interconnections between child labor and fertility (Levy, 1985; Alaka Basu, 1993; Bardhan and Udry, 1999; Chaudhuri, 2000; Fan, 2002; Brown, Deardorff and Stern, 2002).

We shall not enter these myriad subfields of inquiry but move on instead to survey some of the empirical findings of the rapidly growing literature on child labor and then examine what we have learned about policymaking in this area.

\footnotetext{
${ }^{7}$ These can be of two kinds - those where the bargain is within the household and those where the parent bargains with an employer about a child's pay, treating the child as simply an input for generating wealth.
} 


\section{Definitions and Estimates}

According to the latest estimates put out by the ILO there are 211 million children in the age group 5 to 14 years who are 'economically active' and 186.3 million who are 'child laborers'. These figures have to be treated with caution; there are problems with both under-counting and over-counting.

The ILO collected this data by tracking the children's 'work status' over the previous week. It is, however, well-known and has now been documented by Levison $e t$ al (2002) that children's work is notoriously intermittent (for example, seasonal or as needed). That is, they take up and leave jobs much more frequently than adults. So the fact that a child did not work the previous week does not mean that the child has not worked during the previous month or the previous year. To correct for this, Levison et al have worked out an "intermittency multipliers", which allow them to guess at the number of children who do some work from the estimated number based on one week's record. Their work using Brazilian data shows that the real number will be higher by $72 \%$ to $94 \%$. Hence, applying the intermittency multiplier to the ILO estimate would give us a figure of economically active children somewhere between 365 to 409 million.

Secondly, there is the problem of undercounting the labor of the girl child. The ILO clarifies that, as with most organizations engaged in collecting data on child labor, it ignores the unpaid and not-for-market work that is done in the household, such as household chores. It is not surprising that boys turn out to be doing more labor than girls, not only in this new ILO data but in nineteenth century British data as well. ${ }^{8}$ Girls do a

\footnotetext{
${ }^{8}$ According to the Census of England and Wales, in $1861,36.9 \%$ of boys in the age group 10 to 14 years were working and the figure for girls was 20.5\% (Cunningham, 1996). For historical accounts of child labor and the related debate on international labor standards, see Goldin (1979), Weiner (1991, chapter 6), Cunningham and Viazzo (1996), Moehling (1999), Engerman (2002), and Humphries (2002).
} 
disproportionate amount of household work—often for absurdly long hours making schooling impossible — and, if this is ignored, girls' work appears to be less. As Burra (1997, p.204) points out in her exhaustive study of child labor in India, much of female child labor appears "invisible to the casual observer." But when we do carefully estimate child work, including unpaid household work, it turns out that girls do more labor than boys. Burra provides evidence of specific industries and rural work where girls easily outnumber boys ${ }^{9}$. Research by Cigno and Rosati (2000), using data collected by the National Council of Economic Research, which include statistics on household work, shows that girls do $33 \%$ more work than boys (see Table 1).

Hence, ignoring household work encourages gender injustice and also gives an erroneously low figure of incidence of child labor. If this correction of $33 \%$ is made to the above estimate of economically active children, the number goes up to somewhere between 425 million and 477 million. This would mean close to $40 \%$ of the world's children are economically active.

Though this number seems high, both corrections are reasonable. What may have gone wrong? In trying to answer this we come up against the opposite problem, to wit, that of over-count. The ILO treats a child as economically active if the child did one hour or more work in the previous week. Surely that is too generous a definition and would tend to include too many children in its ambit. And this is so not only for developing countries but also for industrialized nations, where children do often deliver newspapers and baby sit and, at times, work in (declining) agricultural activities.

\footnotetext{
${ }^{9}$ Jayaraj and Subramanian (2002) have created an "index of disadvantage" for working children, and find that girls are more disadvantaged than boys in terms of this index in Tamil Nadu, India.
} 
Table 1

Child Labor 6-16, Participation Rates (\%) by Gender, India, 1994

\begin{tabular}{|l|c|c|c|c|c|}
\hline & Agricultural & $\begin{array}{c}\text { Non- } \\
\text { Agricultural }\end{array}$ & Household & Total Work & $\begin{array}{c}\text { School } \\
\text { Enrollment }\end{array}$ \\
\hline Boys & 5.2 & 2.3 & 5.3 & 12.8 & 71.5 \\
\hline Girls & 4.5 & 1.7 & 10.5 & 16.6 & 57.0 \\
\hline All & 4.9 & 1.9 & 7.7 & 14.6 & 64.7 \\
\hline
\end{tabular}

Source: Cigno and Rosati (2001), based on the Human Development of India Survey, conducted by NCAER, New Delhi.

For this reason, it is preferable to use ILO's estimates on “child labor" instead of that of child work or economically active children. A "child laborer" is defined by the ILO as follows. For those in the age group 5-11 it is treated as synonymous with "economically active"; for those in the age group 12-14 it consists of those who do 14 hours or more of non-hazardous work per week and those who do one hour or more of hazardous work per week. This definition leads us to the figure of 186.3 million child laborers in the world, mentioned above. This and some related statistics are presented in Table 2. Though we have some differences even with this calculation ${ }^{10}$, these are small in terms of net effect. Hence, in this paper we treat Table 2 as the summary description of current global child labor. ${ }^{11}$

\footnotetext{
${ }^{10}$ It is, for instance, not clear that, even for children below the age of 12 years, one hour of work per week (about 10 minutes a day) should have a child count as a child laborer.

${ }^{11}$ In recent times policymakers and academics have tried to take a more nuanced stance on child labor, paying special attention to the worst forms of child labor, which includes hazardous work and forced labor. This has been reflected in conventions, such as ILO Convention 182 and certain laws, like the Sander's
} 
Table 2

Child Labor, 2000, Ages 5-14, Global

\begin{tabular}{|l|c|c|c|c|c|}
\hline & $\begin{array}{c}\text { Child Labor } \\
\text { (millions) }\end{array}$ & $\begin{array}{c}\text { Children in } \\
\text { Hazardous } \\
\text { Work } \\
\text { (millions) } \\
\mathbf{( 2 )}\end{array}$ & $\begin{array}{c}\text { Child } \\
\text { Population } \\
\text { (millions) }\end{array}$ & $\begin{array}{c}\text { Child Labor } \\
\text { Participation } \\
\text { Rate (\%) }\end{array}$ & $\begin{array}{c}\text { Hazardous } \\
\text { Work } \\
\text { Participation } \\
\text { Rate (\%) } \\
\mathbf{( 2 ) / ( 3 )}\end{array}$ \\
\hline Boys & 97.8 & 61.3 & $\mathbf{( 3 )}$ & $\mathbf{( 1 ) / ( 3 )}$ & 9.9 \\
\hline Girls & 88.5 & 50.0 & 583.1 & 15.9 & 8.6 \\
\hline All & 186.3 & 111.3 & $1,199.4$ & 15.5 & 9.3 \\
\hline
\end{tabular}

Source: ILO (2002), Tables 1, 6, and 8, and computations based on them.

\section{The Determinants and Consequences of Child labor}

Over the last ten years, thanks to a large number of multi-purpose household surveys, a few surveys explicitly focused on child labor, and a substantial amount of econometric research based on these statistics, economists are beginning to map the causes and determinants of child labor and acquire an understanding, which, even though far from complete, is far-reaching ${ }^{12}$. Some of the causes identified by this recent research corroborate what many may have expected intuitively. But there are also findings which are either unexpected or concern matters on which we may not have had a prior opinion.

One of the most expected and at the same time contentious determinant of child labor is poverty. This was introduced as the "luxury axiom" in the theory section, above. The role of poverty has been the cornerstone of a lot of thinking regarding child labor. ${ }^{13}$ Casual empiricism seems to confirm its significance. Even in very poor nations, where

Amendment in the U.S. (see discussion in Basu, 2001). Hence, we included the ILO estimates on hazardous labor in this table.

${ }^{12}$ For a comprehensive overview of the state and causes of child labor around the world see U.S.

Department of Labor (2000). For a more eclectic review, mainly of the World Bank's research in this area, see Bhalotra and Tzannatos (2002). 
child labor is widespread and all human beings are subject to the same laws, one, nevertheless, does not find the children of doctors, lawyers, professors and, in general, the middle classes, to be laboring. A recent study by Nagaraj (2002) on the beedi industry in Tamil Nadu and Karnataka, India, show that the number children in the agegroup 5 to 14 years, attending school, rises strictly monotonically as the household monthly per capita expenditure rises from the category "Less than Rs. 120 " to "Rs. 455 to 560 " with nine intermediate categories of increasing expenditure. In the absence of other data, Nagaraj treats schooling as a kind of complement of child labor. This may not be completely valid, as we mentioned in subsection 2.3 , but it does seem to broadly confirm the hypothesis that rising income takes children away from work and into schooling.

At a more macro level, we know that as nations have become richer, the incidence of child labor has tended to fall. In China, the sharp decline in child labor began in the 1970s and has persisted till now. Thailand in the decade 1985-1995 experienced average annual growth of $9 \%$ and the participation rate of children aged 14-15 years (for whom comparable information exists) was halved to $21 \%$ (Tzannatos, 2003). In India, also, the participation rate of child labor has declined since the 1970s though less sharply than China (ILO, 1996). In the case of China we know that the growth rate of GDP has been particularly high since the seventies; India's growth rate has been higher through the 80 s and 90s compared to the previous decades, though not as high as in China.

\footnotetext{
${ }^{13}$ See Jayaraj (1993), Basu and Van (1998, 1999), Basu (1999), Swinnerton and Rogers (1999), Freije and Lopez-Calva (2000), Ray (2000, 2000a), Bhalotra (2002), Nagaraj (2002).
} 
While all this suggests that the luxury axiom is probably valid empirically, we would be justified in not accepting these broad-brush descriptions as 'proof'. Fortunately, there are now micro studies that seem to reinforce the role of poverty. ${ }^{14}$

Vietnam is a country that has witnessed rapid growth through the nineties. It also happens to be a country for which there were two household surveys done five years apart, in, respectively, 1992-93 and 1997-98. And of the 4,800 households covered in the first round, 4,305 were part of the second survey, thereby providing us with a convenient panel data set. In a recent paper, Edmonds (2001) does a persuasive analysis of 3,436 of these households that were classified as rural. During these five years, Vietnam's GNP per capita grew at the rate of $6.5 \%$ per annum and child labor, between the ages of 6 and 15 years, fell by $26 \%$ over the five years. The question that Edmonds asks is whether this decline in child labor can be attributed to the rise in the standard of living.

Urban households are kept out because of the complexities caused by the great heterogeneity in the types of labor done by children and also because they are relatively much less important a contributor to the nation's total child labor. Many alternative explanations are considered and attention is paid not just to child labor in the aggregate but to different kinds of child labor, such as in agriculture and in 'family business'.

The decline in child labor seems unequivocal and across age groups and kinds of child labor, as is evident from Table 3.

\footnotetext{
${ }^{14}$ Some early research found that the effect of adult income was often negative but small (and at times insignificant) after controlling for other variables. Most likely this is the result of measurement errors, failure to take into account the role of wealth (especially land), inappropriately controlled endogeneity, and arbitrary functional forms used in the estimation (Bhalotra and Tzannatos, 2002).
} 


\begin{tabular}{|c|c|c|c|c|c|c|c|c|}
\hline \multicolumn{7}{|c|}{ Table 3 } \\
Child Labor Participation (probability), Vietnam, 1993 and 1998 \\
\hline Age & Work & $\begin{array}{c}\text { Outside } \\
\text { House }\end{array}$ & $\begin{array}{c}1993 \\
\text { Agricultural }\end{array}$ & $\begin{array}{c}\text { Family } \\
\text { Business }\end{array}$ & Work & $\begin{array}{c}\text { Outside } \\
\text { House }\end{array}$ & Agricultural & $\begin{array}{c}\text { Family } \\
\text { Business }\end{array}$ \\
\hline 10 & 0.31 & 0.00 & 0.29 & 0.03 & 0.17 & 0.00 & 0.16 & 0.00 \\
\hline 11 & 0.36 & 0.01 & 0.33 & 0.04 & 0.27 & 0.00 & 0.26 & 0.02 \\
\hline 12 & 0.46 & 0.03 & 0.38 & 0.07 & 0.34 & 0.00 & 0.32 & 0.02 \\
\hline 13 & 0.54 & 0.03 & 0.47 & 0.06 & 0.42 & 0.02 & 0.39 & 0.05 \\
\hline 14 & 0.67 & 0.05 & 0.56 & 0.11 & 0.49 & 0.04 & 0.42 & 0.07 \\
\hline 15 & 0.77 & 0.09 & 0.66 & 0.09 & 0.61 & 0.04 & 0.52 & 0.10 \\
\hline
\end{tabular}

Source: Edmonds (2001), based on Vietnam Living Standards Surveys (VLSS).

Edmonds develops a new, non-parametric variation of the Blinder-Oaxaca decomposition approach in order to determine the extent of the decline in child labor that can be attributed to the decline in poverty. He first runs a nonparametric (locally linear) regression to map the cross-sectional relation between the incidence of child labor and household income (measured by household expenditure per capita) using the 1993 data. This cross-sectional relation is then used to predict the amount of child labor in 1998 taking account of the large increase in per capita expenditure that occurred during this interval. He finds strong corroboration of the hypothesis that it is rising living standards that cause child labor to decline. In particular, he finds that increase in household income can explain $94 \%$ of the decline in child labor for households at the poverty line.

The axiom that poverty causes child labor has, however, not gone unquestioned. There are empirical studies (for example, Ray, 2000a, in his study of Pakistan) that have 
failed to find a positive relation between poverty and child labor. But it is arguable that the income that a household targets as minimum acceptable may not coincide with the nation's or region's official poverty line. So if we use the head-count ratio based on the official poverty line to measure poverty, this may not explain the incidence of child labor. Another critique of poverty-based explanations of child labor has come from Bhalotra and Heady (2002), who have tried to show, using data from Pakistan and Ghana, that households which own (or operate) larger amounts of land tend to make their children work more. Since a larger land-holding would typically mean greater wealth, this seems to suggest that greater poverty does not lead to greater child labor.

The main reason why greater land ownership may contribute to higher child labor is, as Bhalotra and Heady recognize, that, in the absence of a properly functioning labor market, owning or controlling land amounts to having the opportunity for more productive use of the household's labor, including child labor. Hence, if two households are equally disinclined to send their children to work but one has more land, then that household may choose to make the children work simply because such a household finds that child labor is more rewarding than the other. So it is not surprising that, on the margin, land-ownership makes a difference.

It is interesting to note that Edmonds and Turk (2002) found something similar in the case of Vietnam. Households that start their own business are more likely to send the children to work ${ }^{15}$. The reason must be the same. A household that starts its own business is like a household with a lot of land. It has greater opportunity to use its own labor more productively. This does not mean that poverty is not a determinant of child labor, but

\footnotetext{
${ }^{15}$ The same is confirmed by Canagarajah and Coulombe (1997). Kanbargi and Kulkarni (1991) found that in Karnataka, India, having a larger amount of cattle can mean a higher incidence of child labor.
} 
simply that child labor, like all other inputs, responds also to incentives and opportunities. Our hunch is that if we had sufficiently disaggregated data for households, ranging from those that own no land to those that have very large quantities of land, we would find a non-linear relation with child labor first rising, as land ownership rose and eventually falling. The latter would be because, beyond a point, the wealth of the household would kick in as the dominant factor, causing child labor to decline.

The story gets even more complicated when we begin to study the relation between human capital formation and child labor, and the inter-generational dynamics of child labor. Let us first begin by examining the relation between child labor, schooling and human-capital formation ${ }^{16}$. Does child labor hurt education and the acquisition of human capital? Most of us, when we act as parents and not professional economists or sociologists, take the answer to this for granted. We presume that child labor is inimical to education and the growth of a person into a productive human being. But what we aspire for our children is very different from what a person living on the edge of the poverty line can even think of (Appadorai, 2002). Hence, it is entirely possible that for those living such a precarious life there is indeed a tradeoff between education and wellbeing, at least in their perception. For the child of a poor craftsman, the proposition that it is better to learn the parent's craft than go to school is not something that can be dismissed out of hand. Hence, there is a case for investigating that the data tells us.

The existing literature seems to support the view that, though some work can help in acquiring human capital, by teaching individuals the skills and attitudes needed to

\footnotetext{
${ }^{16}$ This is a topic with a rapidly growing literature. See, for instance, Rosenzweig and Evenson (1977), Maitra and Ray (2002), Ray (2002), Deb and Rosati (2002) and Rosati and Rossi (2002).
} 
work well as adults and, at times, by enabling them to earn the money that is needed to go to school (French, 2002; Psacharopoulos, 1997), in general child labor impedes the acquisition of education and human capital. This comes out quite clearly from an analysis of three rounds of data, 1982, 1988 and 1996, of the Pesquisa Nacional por Amostragem a Domicilio (PNAD) from Brazil. Emerson and Souza’s (2002a) regression analysis using this data shows that starting to work younger results in foregone earnings as an adult and this is true for men and women. If we break up the starting age for work into three categories: below 9 years, 10 to 13 years, 14 to 17 years, it is found that the loss of earnings is greatest for the first category, followed by the second and that followed by the third. For reasons that are not altogether clear, starting work earlier is relatively more costly for girls than for boys. This needs further investigation since another study that we know that looks at this — Swaminathan (1997), using data from Bhavnagar, Gujaratfinds the opposite result, namely, that boys lose out more by joining the labor force early. Are these foregone earnings caused by the fact that child labor interferes with schooling? Here an interesting difference shows up between those who start work as children (that is, below the age of 13 years) and those who begin work as adolescents (14 to 17 years). If we run the regression with and without the person's own education as an explanatory variable, these two categories show up differently. In particular, Emerson and Souza (2002a) show that for the adolescents the wage foregone is a direct outcome of education not acquired (that is, time spent away from school, at work). On the other hand, for children, there are negative effects over and above, the loss caused by lack of schooling. Child labor (as opposed adolescent labor) thwarts the acquisition of human 
capital by causing a loss of education and through other channels, for instance, by damaging health or affecting attitudes ${ }^{17}$.

One intriguing relation between child labor and education occurs across siblings. As noted earlier, while for a particular child (barring some small exceptions) work cuts into education, across siblings in poor families, work and education often seem to go together. That is, one child's labor may make it possible for another child to go to school (see Morduch, 2000, for a general discussion of this). While this phenomenon-let us call it "sibling complementarity ${ }^{18 ",-i s, ~ a t ~ o n e ~ l e v e l, ~ q u i t e ~ o b v i o u s, ~ i t ~ h a s ~ n o t ~ r e c e i v e d ~ e n o u g h ~}$ attention in this literature. An exception is the paper by Emerson and Souza (2002b) which analyzes Brazil's 1998 PNAD data and establishes systematic relationships between birth-order, on the one hand, and propensity to go to school and work, on the other. They show that the last-born male child is less likely to work than his other siblings. This seems to be quite universal. Almost as widespread is the fact that the firstborn female child is less likely to attend school than others. Of course, this sibling complementarity will show up in households which are moderately poor, since in rich households typically all children will be out of work and in school and in very poor households it will be the reverse. What the fact of sibling complementarity suggests is that in these moderately poor households some children are kept away from school (and sent to work or made to look after the household) in order to enable other children to go to school. This 'fact' will have important moral and policy questions, especially since birth-order also seems to be tied to gender with the girl child often being used to enable

\footnotetext{
${ }^{17}$ The relation between the amount of child labor and the acquisition of human capital is studied by Rosati and Rossi (2002).
} 
the younger male sibling to go to school. It is not possible for us to say much more about this, since not much more is known. But we wanted to flag this topic as an important one, deserving further research and attention.

Finally, let us turn to the subject of inter-generational dynamics. That poverty transmits from one generation to another and this has been the case through the ages is known and documented (Horrell, Humphries and Voth, 2001). What they show, in addition, is that downward shocks, not only leave families worse off but can affect adversely the formation of human capital among the descendants of the family. They reach this conclusion by studying a very unusual nineteenth-century data set.

The Marine Society was established in Britain in 1756 to recruit poor, unemployed boys for the Navy. From 1770 to 1861 the Marine Society kept detailed records of the boys interviewed, including their socio-economic background. Horrell, Humphries and Voth use this data set to show that poverty in one generation transmits to future generations in the form of lower human capital. This causes dynastic poverty traps. They also try to show that this pernicious effect of poverty can be countered by having systems of social security, by demonstrating how Britain's Old Poor laws did have a mitigating effect on this process.

Turning to contemporary times and to the specific question of child labor, we find evidence of dynastic traps. Wahba (2002) analyses the 1988 Labor Force Sample Survey of Egypt, which involves a nationally representative sample of 10,000 households. Her analysis is based on 10742 children of the age group 6 to 14 years for whom full information on schooling work and parental characteristics are available. It is worth

\footnotetext{
${ }^{18}$ The "complementarity" refers to the relation between child labor and schooling. For a single child these two are typically substitutes (though of course there are exceptions) but, across siblings, these are more
} 
noting as a digression that she finds strong support of the axiom that it is hardship that makes parents send their children to work. She finds that a $10 \%$ rise in the market wage rate for illiterate men results in a decrease in the probability of child labor by $22 \%$ for boys and $13 \%$ for girls.

Wahba develops a bivariate probit model, allowing for the decision regarding schooling and work to be simultaneous and interdependent. She finds that a parent who was a child laborer has a higher probability of his or her child being a laborer. The probability of a boy working rises by $10 \%$ if the boy's mother worked as a child and by $5 \%$ if the boy's father worked as a child.

The same phenomenon has been modeled and empirically tested by Emerson and Souza (2002) using PNAD data for Brazil. They actually go onto ask a further question. If a person works as a child, would this result in a rise in the probability of his or her child working by more than that can be explained by the fact that the person will be poor as an adult (by virtue of having been a child worker) and therefore compelled to send the child to work? The answer is yes. Hence, they surmise the presence of social factors, which cause the perpetuation of child labor through non-income channels. It is, for instance, possible that having been a child laborer oneself affects ones social norms and attitude to child labor (Basu, 1999; Lopez-Calva, 2003) such that one is more prone to send ones own child to work. ${ }^{19}$ One may question whether there may be genetic channels through which these propensities, such as the one to seek education, transmits from one

\footnotetext{
likely to be complements. Hence, the terminology.

${ }^{19}$ In a study of India that does not directly relate to child labor but is concerned instead with education, Behrman, Foster, Rosenzweig, and Vashishtha (1999) find that a greater amount of schooling by women increases the human capital of the next generation and this effect is, at times, greater than what is obtained directly through schooling. This is caused by "home teaching." They find that children with literate mothers spend, on average, one hour more on study at home than children with illiterate mothers.
} 
generation to another. The answer however seems to be no, based on an ingenious study of comparing orphans with non-orphans in sub-Saharan Africa by Lloyd and Blanc (1996). They find that the guardians with whom the child lives matter more significantly than the child's biological parents. This reinforces the likelihood that it is social factors that Emerson and Souza are capturing in their study.

There are two caveats which are worth mentioning to the empirical results cited earlier which also caution about the confidence of generalization which can be made with respect to policies which are discussed in the next session.

First, the empirical literature on child labor is relatively young. As a result, many studies (some quoted in this paper) report results which are at best treated as preliminary. This can of course be corrected in the course of time but some generic problems, endemic to economic and social research may persist well into the future.

Second, cross-section estimates may omit to capture important lifecycle effects, and more generally estimates can be affected by endogeneity or identification problems. ${ }^{20}$ Also, studies which include as explanatory variables the occupation of adults, land ownership or other income variables may be haunted by multicollinearity. The results for control variables (such as household size, relationship of child to head of household, age of child, birth order of children) may be similarly affected. Omission of some variables from the estimation (simply because data are lacking) may also give rise biases. Since many studies examine simultaneously the relationship between child labor and education, there can be unobserved heterogeneity (for example, in the academic ability of children or health/disability) which can be further conflated by the inclusion of parental education

\footnotetext{
${ }^{20}$ For an extended discussion on each of these problems and their effects on estimation see Bhalotra and Tzannatos (2002).
} 
(a measure of tastes) or nonlinearities in the returns to education. Regional effects, community infrastructure (measured in various ways such as availability of water, electricity and transportation), and local unemployment rates can render the results of different studies even in the same country and year noncomparable. There are often disequilibrium effects (such as migration) which evade researchers. The use of dummies in estimation pose additional complications as do non-economic variables (such as social norms), which can be proxied in different ways or altogether omitted from the estimation.

\section{Policy}

Much of the early debate on child labor was concerned with whether the existence of child labor deserved a policy response. In the heydays of the laissez faire it had seemed to many observers that if child labor was a product of the market then it must be efficient to have child labor. And if one were committed to the efficiency of the market, then it were best — so went the argument — to leave things as they were. The state had no reason to be involved in the market.

The chinks in this argument were obvious enough. Education involves externalities and so a decision taken by an individual or a household may not be in the best interest of society. This argument was cogently summarized by Grootaert and Kanbur (1995) in a paper that has been influential in sparking off debate. Then there was the problem of a child's agency. The decision as to whether a child will work, study, or play, is usually taken by the child's parents or guardians; and the standard consumerssovereignty argument does not apply to cases where one person decides for another. ${ }^{21}$

\footnotetext{
${ }^{21}$ A recent philosophical discussion of this and an examination of what exactly 'voluntary choice' means in the context of child labor occurs in Satz (2002).
} 
Even when one recognizes these caveats, the laissez-faire prescription of nonintervention and waiting for the benefits of growth to trickle down and remove child labor, has been defended by some as a kind of best available strategy. This is the position taken by Nardinelli (1990), who reads the experience of industrial revolution and its aftermath in Britain as evidence of how legal interventions are futile in the face of market forces that gives rise to child labor. A similar line, based on an econometric analysis of American historical data, is taken by Moehling (1999).

We shall however argue, based on our understanding of the modern theory and data, that government intervention for controlling child labor is both desirable and possible. However, one has to craft policy recognizing the powerful market forces that give rise to child labor in the first place and therefore will no doubt respond to any intervention; and also being aware of the many pitfalls and risks of backlash that occur in this area of complex interaction between household economics and market structures.

In conducting this discussion, it is useful to state an important ground rule that we shall follow. Any policy in the area of child labor (including the policy decision not to do anything) must be justified primarily in the interests of the children. In other words, we shall not be interested in arguments such as: "policy x concerning child labor will leave children worse off but is justified in the interest of helping boost the country's exports and through that its GNP”. In brief, we take here a child-centric view of policy.

The policy interventions that we will discuss can be divided into two kinds: 'collaborative' measures and 'coercive' measures.

Collaborative Measures are, broadly speaking, interventions which alter the economic environment of the decision makers, which make them now more willing to let 
children stay away from labor and spend more time on other activities and, especially, schooling. Thus a policy which improves the functioning of adult labor markets, so that adult incomes rise and unemployment falls, is always desirable from the point of view of curtailing child labor. Given that parents, typically, want to keep children away from work and in school, if they find that they have enough income of their own so as to render child labor to be unnecessary, they will themselves tend to withdraw children from work and may be put them in school.

Does this mean that just giving unconditional income subsidies to poor households will curtail child labor? Though we feel the answer will generally be yes, one has to be careful here. From what we have already seen, it is possible that such subsidies will be used to buy land or other businesses and this, in turn, could increase child labor by creating an easy productive environment for employing children.

Closely related to this is the policy of improving credit and insurance markets, so that adults who fall into bad times can borrow money on decent terms and do not need to take their children out of schools and send them to work to help the household ride over the rough patch. The link between credit markets and child labor has been noted in the literature (Baland and Robinson, 2000; Ranjan, 2001).

But, by far the most direct collaborative measures are the ones which reward children who go to school instead of working. Around the world many such interventions have been tried and there is now a small body of empirical literature studying these programs. Bolsa Escola in Brazil ${ }^{22}$ (Bourguignon, Ferreira and Leite,

\footnotetext{
${ }^{22}$ Brazil has another program, PETI (Programa de Erradicacao do Trabalho Infantil), which similar to Bolsa Escola, provides an income subsidy but in the form of a rural targeted transfer program. Comparisons of schooling, child participation, hours worked, academic progress and dangerous work in PETI households versus control households indicate that the program increased academic performance and
} 
2002; Lavinas, Barbosa and Tuorinho, 2003), Progresa in Mexico (Schultz, 2001, Skoufias and Parker, 2003), Red de Protection Social (RPS) in Nicaragua (Maluccio, 2003), food for education program in Bangladesh (Ravallion and Wodon, 2000), mid-day meal schemes in India (Dreze and Kingdon, 1999), the school construction programs in Indonesia (Duflo, 2000) and the "back to school" measures aimed to prevent a rise in child labor and sustain school enrolments in Indonesia after the financial crisis (Filmer and Sayed, 1999) are all examples of policy intervention which builds in incentives for parents to send their children to (or for autonomous children to go to) school. Most of these programs find that schooling does in reality respond to such incentives. Thus Dreze and Kingdon find that female school participation is $15 \%$ higher when the local school provides a mid-day meal. They find that girls schooling responds more to such incentives than boys schooling. This is an important finding since we need to make special effort to keep girls away from work, which, though often invisible, could add up to more than what boys do.

Mexico's Progresa now extends to to approximately $40 \%$ of all rural families as beneficiaries and can provide large incentives to schooling (including required medical tests and nuitritional programs). In poor areas, the grant that the mother receives if her daughter is enrolled in the $9^{\text {th }}$ grade is 255 pesos per month, which is $44 \%$ of an average male day-laborer's wage or about $2 / 3^{\text {rd }}$ of what a child of this age would earn if she worked full time. Schultz (2001) finds that the program's net effect on enrollment is positive and statistically significant. Skoufias and Parker (2003) estimate that the labor force participation of children aged 12 to 15 years is reduced by $15-25 \%$ relative to the 
probability of participating prior to the program, and that children are much more likely to attend school and to spend more time on school activities. The estimated increase in the education attainment of children dominates the enrolment gains from increased provision of schools.

Nicaragua's Red de Protección Social (RPS) is a conditional cash program modeled after PROGRESA. An evaluation of recipient households in a pilot program against a randomly selected group of comparable households shows that RPS had a significant and substantial effect on schooling matriculation and enrollment during its first year of operation (Maluccio, 2003). Moreover, it led to a substantial reduction in child labor within the target population. In contrast to the Mexico case, these gains occur even at the earliest ages, suggesting that the PROGRESA type interventions may hold promise for the poorest countries with the worst educational outcomes in the region.

Bourguignon, Ferreira and Leite also find that such incentives increase schooling in Brazil's Bolsa Escola program (though it is less successful in mitigating poverty). But does this increase in schooling cause child labor to decrease? Almost always the answer is yes and almost always the answer is that this happens by less than the increase in schooling. In some of the poorest regions, even with subsidies, schooling becomes possible for children only if they can also do a little work to finance their schooling and, presumably, also their consumption. ${ }^{23}$ The above are 'collaborative' measures. They do not require coercion and may not even require any legislative backup.

Coercive measures have been very hotly debated in international fora and policies such as having a 'social clause' which would enable the WTO to take punitive 
action against a country that has child labor have been proposed by many. What position does one take on such coercive measures? Unfortunately, on these there is not enough empirical work. But these are such important matters that we cannot look away from them on that ground. One has to use the best available theory and intuition to take a stand on these, no matter how tentative.

We argue that coercive measures also have their role but need to be used much more carefully than collaborative policies. First of all, hazardous labor ought to be legally banned. It is true that this may cause other forms of hardship to some very poor families in the short run, but to allow for such labor to directly hurt children, who or whose parents often cannot properly assess the long-run damage that such labor can do to them, makes little sense. Even for non-hazardous labor there may be scope for using legislative bans. This is typically closely associated with the theory of multiple equilibria. We have seen above that in static and dynamic models we may often have multiple equilibria with children typically doing better in the equilibrium in which children do not work or do very little work. Should there be such multiple equilibria in an economy, with the economy settled in a situation with high child labor, a legislative ban can deflect the economy to the 'superior' equilibrium and may be justified on that ground.

Such action, however, needs to be preceded by careful empirical evaluation of the situation, since, if there are no multiple equilibria, then such a law can exacerbate the suffering of the children. For one, it can deprive children from work which was essential for their survival. If the law is effective only in some sectors, it can drive child labor underground, to sectors that may be more harmful for the children. And finally, note that

\footnotetext{
${ }^{23}$ Many observers, familiar with the ground realities of the poorest regions of the world, have made the case for making school and work more flexible so that children can combine school with a little bit of work
} 
such laws are typically implemented by imposing a fine on the employer, who employs children in violation of the law. That is exactly how India's Child Labor Deterrence Act, 1986, works. It empowers the state to impose a fine on firms that violate the law by employing children in activities that are disallowed. Such laws can, ironically, have the effect of raising the amount of child labor. The reason is easy to see. By making the employment of children more costly to firms, such a law ensures that child wage will now be lower (for otherwise it is not worthwhile for firms to employ children). Now in case children were working to meet some minimum tolerable income target (for instance, to escape abject poverty), then the lower wages would mean that children have to work longer hours, and often harder, to reach that target. Hence, the slapping of a small fine can have the opposite effect of what is intended.

Partial measures are, in general, a bad idea and this is relevant when we think of global action to deter child labor. This is part of the larger debate on international labor standards. ${ }^{24}$ The two major problems that have concerned economists are, first, that once an instrument of global action is created to thwart the flow of goods from nations that violate minimal labor standards, this will be used for protectionism by the industrialized nations (Bhagwati, 1995; Srinivasan, 1996), and second, that international action to stop child labor inputs into traded goods will simply drive children into the non-traded sector and this may be worse for them (Fallon and Tzannatos, 1998) ${ }^{25}$. In a study of India's

(Siddiqui, 2001, p.19), which may well be the only way that they will be able to get any education. ${ }^{24}$ See Collingsworth, Goold and Harvey (1994), Bhagwati (1995, 2002), Bhagwati and Hudec (1996), Rodrik (1996), Krueger (1996), Maskus (1997), Basu (1999a, 2001), Bachman (2000), Chau and Kanbur (2000), Kabeer (2000), Santoro (2000), Fung, O'Rourke and Sabel (2001), Bardhan (2001), Bagwell and Staiger (2003), Brown, Deardorff and Stern (2002), Krueger (2002), and Singh (2003).

${ }^{25}$ In addition, work is often sub-contracted out to the home-based sector (Mehrotra and Biggieri, 2002) and it is difficult to bring the latter under the law. This makes overall monitoring very difficult. As Standing (2001, p. 17) observes, "Informalization has spread everywhere, including within so-called formal enterprises." 
garment export industry, Stahl and Stalmarker (2002) found little evidence of bonded labor and the 'worst forms' of child labor. This does not preclude these practices occurring elsewhere, but suggests that the export sector is not one where they occur.

There is evidence for both these. It was discussed in Basu (2001) how the Sander's Amendment in the US, which is a desirable amendment to the Tariff Act, meant to prevent forced child labor, has been used to block imports into the US and settle other scores. There is also evidence that some initial attempts to stop child labor in export industries, such as carpets in Nepal, has driven children into prostitution (UNICEF, $1995)^{26}$. And conversely, there is evidence that market integration may lead to less child labor. Edmonds and Pavcnik (2002) found that opening up the Vietnam economy resulted in rice price to rise and this caused child labor to decline. Hence, while there is scope for coordinated action among developing countries to raise labor standards (so as to discourage international capital from fleeing from one country to another), we must be wary of policies that use punitive action, like trade sanctions, to enforce labor standards.

It is not surprising that there is no one simple policy measure to eradicate child labor. Its persistence through two centuries is testimony that there is no easy solution. Yet today we understand much better the causes of child labor, and have the opportunity to craft policy that can sharply reduce and ultimately eradicate it.

\footnotetext{
${ }^{26}$ For an excellent study of the general problem of trafficking in girls in Nepal see the IPEC study by KC, Subedi, Gurung and Adhikari (2001).
} 


\section{References}

Admassie, A. (2002), 'Exploring the High Incidence of Child Labor in Sub-Saharan Africa', African Development Review, vol. 14, 251-75.

Andvig, J. (2000), 'An Essay on Child Labor in Sub-Saharan Africa - A Bargaining Approach', mimeo: The World Bank.

Appadorai, A. (2002), 'The Capacity to Aspire', mimeo: Chicago University.

Bachman, S.L. (2000), 'The Political Economy of Child Labor and Its Impact on International Business', Business Economics, vol. 35.

Bagwell, K. and Staiger, R. (2000), 'The Simple Economics of Labor Standards and GATT,' in Deardorff, A.V. and Stern, R.M. (eds.) Social Dimensions of U.S. Trade Policy, Ann Arbor: University of Michigan Press.

Baland, J.-M., and Robinson, J. (2000), ‘A Model of Child Labor', Journal of Political Economy, vol. 108.

Bardhan, P.K. (2001), ‘Some Up, Some Down’, Boston Review, February, vol. 26.

Bardhan, P.K. and Udry, C. (1999), Development Microeconomics, Oxford: Oxford University Press.

Basu, K. (1999), 'Child Labor: Cause, Consequence, and Cure, with Remarks on International Labor Standards', Journal of Economic Literature, vol. 37.

Basu, K. (1999a), 'International Labor Standards and Child Labor', Challenge, vol. 42.

Basu, K. (2000), 'The Intriguing Relationship between Adult Minimum Wage and Child Labor', Economic Journal, vol. 110.

Basu, K. (2001), 'Compacts, Conventions, and Codes: Initiatives for Higher International Labor Standards', Cornell International Law Journal, vol. 34.

Basu, K. (2002), 'A Note on Multiple General Equilibrium with Child Labor', Economics Letters, vol. 74.

Basu, K. and Van, P.H. (1998), 'The Economics of Child Labor', American Economic Review, vol. 88.

Basu, K. and Van, P.H. (1999), 'The Economics of Child Labor: Reply', American

Economic Review, vol. 89. 
Basu, Alaka (1993), 'Family Size and Child Welfare in an Urban Slum: Some Disadvantages of Being Poor but Modern', in Lloyd, C. (ed.), Fertility, Family Size and Structure, New York: Population Council.

Basu, Arnab and Chau, N. (2002), 'Targeting Child Labor in Debt Bondage: Evidence and Theory', mimeo: Cornell University.

Behrman, J.R., Foster, A.D., Rosenzweig, M. R. and Vashishtha, P. (1999), 'Women's Schooling, Home Teaching, and Economic Growth', Journal of Political Economy, vol. 107.

Bell, C. \& Gersbach, H. (2001), 'Child Labor and the Education of a Society', mimeo: Sudasien Institute, Heidelberg.

Bhagwati, J. (1995), 'Trade Liberalization and 'Fair Trade' Demands: Addressing the Environmental and Labor Standards Issues', World Economy, vol. 18.

Bhagwati, J. (2002), Free Trade Theory, Princeton: Princeton University Press.

Bhagwati, J. and Hudec, R., eds. (1996), Fair Trade and Harmonization, Vol.1: Economic Analysis, Cambridge, MA: MIT Press.

Bhalotra, S. (2000), 'Is Child Work Necessary?' mimeo: London School of Economics.

Bhalotra, S. and Heady, C. (2002), 'Child Farm Labor: The Wealth Paradox', Social Protection Discussion Paper No. 02XX, The World Bank.

Bhalotra, S. and Tzannatos, Z. (2002), 'Child Labor: What Have We Learnt?', Social Protection Discussion Paper No. 0234, The World Bank.

Bourguignon, F., Ferreira, F.H.G. and Leite, P.G. (2002), 'Ex ante Evaluation of Conditional Cash Transfer Programs: The Case of Bolsa Escola', mimeo: DELTA, Paris.

Brown, D., (2000), 'A Transactions Cost Politics Analysis of International Child Labor Standards, in Deardorff, A. and Stern, R. (eds.), Social Dimensions of US Trade Policy, Ann Arbor: University of Michigan Press.

Brown, D. Deardorff, A., Stern, R. (2002), 'Child Labor: Theory, Evidence and Policy', in Basu, K., Horn, H., Roman, L., and Shapiro, J. (eds.), International Labor Standards: History, Theories and Policy, Blackwell, forthcoming.

Burra, N. (1997), Born to Work: Child Labor in India, Delhi: Oxford University Press. 
Canagarajah, S. and Coulombe, S. (1997), 'Child Labor and Schooling in Ghana', World Bank, Policy Research Working Paper no. 1834.

Chandrasekhar, C.P. (1997), 'The economic Consequences of the Abolition of Child Labour: An Indian Case Study,” The Journal of Peasant Studies, vol. 24.

Chau, N. and Kanbur, R. (2000), 'The Race to the Bottom, from the Bottom', mimeo: Cornell University.

Chaudhuri, D.P. (1997), 'A Policy Perspective on Child Labor in India with Pervasive Gender and Urban Bias in School Education', Indian Journal of Labor Economics, vol. 30 .

Chaudhuri, S. (2000), 'Incidence of Child Labour, Free Education Policy and Trade Liberalization in a Small Open Economy: A Theoretical Analysis.' Mimeo: University of Calcutta.

Cigno, A. and Rosati, F.C. (2001), 'Why Do Indian Children Work and is it Bad for Them?' mimeo: University of Florence.

Cigno, A., Rosati, F. and Tzannatos, Z. (2002), Child Labor Handbook, Washington: The World Bank.

Collingsworth, T., Goold, F. William and P. F. Harvey (1994), 'Time for a Global New Deal,' Foreign Affairs, vol. 73.

Cunningham, H. (1996), 'Combating Child Labor: The British Experience', in Cunningham and Viazzo (1996).

Cunningham, H. and Viazzo, P. P., eds., (1996), Child Labor in Historical Perspective, 1800-1985: Case Studies from Europe, Japan and Colombia, Florence: UNICEF.

Deb, P. and Rosati, F. (2002), 'Determinants of Child Labor and School Attendance: The Role of Household Unobservables.' Mimeo: IUPUI.

Dehejia, R. H. and Gatti, R. (2001), 'Child Labor: The Role of Income Variability and Access to Credit in a Cross Section of Countries.' mimeo: Columbia University.

Dessy, S. (2000), 'A Defence of Compulsive Measures against Child Labor', Journal of Development Economics, vol. 62, 261-75.

Dessy, S. and Pallage, S. (2001), 'Child Labor and Coordination Failures', Journal of Development Economics, vol. 65. 
Dessy, S. and Pallage, S. (2002), 'Why Ban the Worst Forms of Child Labor', mimeo: Universite Laval, Canada.

Dixit, A. (2000), 'Comment on "A Transaction Cost Politics Analysis of International Child Labor Standards", in Deardorff, A.V. and Stern, R.M. (eds.) Social Dimensions of U.S. Trade Policy, Ann Arbor: University of Michigan Press.

Doepke, M. and Zilibotti, F. (2002), 'Voting with Your Children: A Positive Analysis of Child Labor Laws', mimeo: University of California at Los Angeles.

Dreze, J. and Kingdon, G. (1999), 'School Participation in Rural India', London School of Economics, Development Economics Discussion Paper No.18.

Duflo, E. (2000), 'Schooling and Labor Market Consequences of School Construction in Indonesia', NBER Working Paper No. 7860.

Edmonds, E. (2001), 'Will Child Labor Decline with Improvements in Living Standards?', Dartmouth College Working Paper \# 01-09.

Edmonds, E. and Pavnick, N. (2002), 'Does Globalization Increase Child Labor? Evidence from Vietnam,' NBER Working Paper \#W8760.

Edmonds, E. and Turk, C. (2002), 'Child Labor in Transition in Vietnam', World Bank Policy Research paper \#2774.

Emerson, P. and Souza, A. (2002), 'Is There a Child Labor Trap? Intergenerational Persistence of Child Labor in Brazil', Economic Development and Cultural Change, forthcoming.

Emerson, P. and Souza, A. (2002a), 'The Effect of Adolescent Labor on Adult Earnings and Female Fertility in Brazil', mimeo: University of Colorado, Denver.

Emerson, P. and Souza, A. (2002b), 'Birth Order, Child Labor and School Attendance in Brazil', mimeo: University of Colorado, Denver.

Engerman, S. (2003), 'The History and Political Economy of International Labor Standards', in Basu, K., Horn, H., Roman, L., and Shapiro, J. (eds.), International Labor Standards: History, Theories and Policy, Blackwell.

Epple, D. and Romano, R.E. (1996), 'Ends against the Middle: Determining Public Service Provisions when there are Private Alternatives, Journal of Public Economics, vol. 62.

Fallon, P. and Tzannatos, Z. (1998), Child Labor : Issues and Directions for the World Bank, Washington, D.C. : The World Bank. 
Fan, C. S. (2002), 'Child labor and the Interaction between the Quantity and Quality of Child Labor', mimeo: Lingnan University, Hong Kong.

Filmer, D. and Sayed, H. (1999) 'Impact of Economic Crisis on Basic Education in Indonesia'. East Asia and Pacific Region Working Paper, the World Bank.

Freije, S. and Lopez-Calva, L.-F. (2000), 'Child Labor, School Attendance and Poverty in Mexico and Venezuela', mimeo: El Colegio de Mexico.

French, J. L. (2002), 'Adolescent Workers in the Third World Export Industries: Attitudes of Young Brazilian Shoe Workers', Industrial and Labor Relations Review, vol. 55.

Fung A., O'Rourke, D. and Sabel, C. (2001), 'Stepping Up Labor Standards', Boston Review, February, vol. 26.

Galor, O. and Weil, D. N. (1996), 'The Gender Gap, Fertility, and Growth', American Economic Review, vol. 86.

Genicot, G. (2000), ‘An Efficiency Wage Theory of Child Labor', mimeo: University of California at Irvine.

Glomm, G. and Ravikumar, B. (1998), 'Opting out of Publicly Provided Services: A Majority Voting Result', Social Choice and Welfare, vol. 15.

Goldin, C. (1979), 'Household and Market Production of Families in a Late Nineteenth -Century American Town', Explorations in Economic History, vol. 16.

Granovetter, M. and Soong, R. (1983), 'Threshold Models of Diffusion and Collective Behavior,' Journal of Mathematical Sociology, vol. 9, 165-79.

Grimsrud, B. and Stokke, L.J. (1997), 'Child Labor in Africa: Poverty or Institutional Failures? The Case of Egypt and Zimbabwe', Fafo Report 233.

Grootaert, C. and Kanbur, R. (1995), 'Child Labor: An Economic Perspective', International Labour Review, vol. 134.

Grootaert, C. and Patrinos, H., eds. (1999), The Policy Analysis of Child Labor, New York: St. Martin's Press.

Grootaert, C. and Patrinos, H., (2002), 'A Four-Country Comparative Study of Child Labor', mimeo: The World Bank.

Gupta, M.R. (2000), 'Wage Determination of a Child Worker: A Theoretical Analysis', Review of Development Economics, vol. 4. 
Hazan, M. and Berdugo, B. (2002), 'Child Labor, Fertility, and Economic Growth', Economic Journal, forthcoming.

Horrell, S., Humphries, J. and Voth, H.J. (2001), 'Destined for Deprivation : Human Capital Formation and Intergenerational Poverty in Nineteenth-Century England', Explorations in Economic History, vol. 38, 339-66.

Humphries, J. (2002), ‘Child Labour: The Experience of Today's Advanced Economies and the Lessons of the Past', mimeo: Oxford.

ILO (1996), Economically Active Populations: Estimates and Projections, 1950-2010, Geneva: ILO.

ILO (2002), Every Child Counts: New Global Estimates on Child Labor, Geneva: International Labor Organization.

Iversen, V. (2002a), 'Idiosyncrasies of Child Labor in Peasant Households in Sub-Saharan Africa: Anthropological Observations and the Economics of Labor Obligations and Exchange,' Mimeo: University of East Anglia.

Iversen, V. (2002), ‘Autonomy in Child Labor Migrants’, World Development, vol. 30.

Jacoby, H.G. and Skoufias, E. (1997), 'Risk, Financial Markets, and Human Capital in a Developing Country,' Review of Economic Studies, vol. 64.

Jafarey, S. and Lahiri, S. (2002), 'Will Trade Sanctions Reduce Child Labor? The Role of Credit Markets', Journal of Development Economics, vol. 68.

Jayaraj, D. (1993), 'Labor Force Participation of Children in Rural India,' Madras Institute of Development Studies, Working Paper No. 116.

Jayaraj, D. and Subramanian, S. (2002), 'Child Labor in Tamil Nadu in the 1980s', Economic and Political Weekly, vol. 37, March 9.

Jensen, P. and Nielsen, H.S. (1997), 'Child Labor or School Attendance? Evidence from Zambia', Journal of Population Economics, vol. 10.

Kabeer, N. (2000), The Power to Choose: Bangladeshi Women and Labor Market Decisions in London and Dhaka, London : Verso.

Kanbargi, R. and Kulkarni, P.M. (1991), 'Child Work, Schooling, and Fertility in Rural Karnataka,' in Kanbargi, R., ed., (1991), Child Labor in the Indian Subcontinent, New Delhi: Sage Publications.

KC, B.K., Subedi, G., Gurung, Y.B. and Adhikari, K.P. (2001), 'Trafficking in Girls with Special Reference to Prostitution: A Rapid Assessment', IPEC, ILO, Geneva. 
Krueger, Alan (1996), 'International Labor Standards and Trade,' Annual World Bank Conference on Development Economics.

Krueger, Alan (2002), 'The Political Economy of Child Labor', in Basu, K., Horn, H., Roman, L. and Shapiro, J. (eds.), International Labor Standards: History, Theories and Policy, Blackwell, forthcoming.

Krueger, D. and Tjornhom, J. (2001) 'Economic Inequality and the Emergence of Child Labor Laws,' Mimeo: Stanford University.

Lavinas, L., Barbosa, M.L., and Tuorinho, O. (2003), 'An Evaluation of the Urban Bolsa Escola in Brazil: The Recife Experience' in P.F.Orazem, G. Sedlacek and Z. Tzannatos (eds; forthcoming) 'Child Labor and Education in Latin America'. Washington DC: InterAmerican Development Bank and World Bank.

Levision, D., Anker, R., Ashraf, S., and Barge, S. (1998 ), 'Is Child Labor really necessary in India's Carpet Industry?' in Anker, R., Barge, S., Rajagopal, S. and Joseph, M.P. (eds.) Economics of Child Labor in Hazardous Industries of India, New Delhi: Hindustan Publishers.

Levison, D., Hoek, J., Lam, D. and Duryea, S. (2002), 'Implications of Intermittent Employment for Child labor Estimates', mimeo: University of Minnesota.

Levy (1985), 'Cropping Pattern, Mechanization, Child Labor, and Fertility Behavior in a Farming Economy: Rural Egypt,' Economic Development and Cultural Change, vol. 33.

Lindbeck, A. Nyberg, S. and Weibull, J. (1999), 'Social Norms and Economic Incentives in the Welfare State', Quarterly Journal of Economics, vol. 114, 1-35.

Lloyd, C. B. and Blanc, A. K. (1996), 'Children's Schooling in Sub-Saharan Africa: The Role of Fathers, Mothers and Others', Population and Development Review, vol. 22.

Lopez-Calva, L.F. (2003), 'Social Norms, Coordination and Policy Issues in the Fight Against Child Labor', in Basu, K., Horn, H., Roman, L. and Shapiro, J. (eds.), International Labor Standards: History, Theories and Policy, Blackwell.

Maitra, P. and Ray, R. (2002), 'The Joint Estimation of Child Participation in Schooling and Employment: Comparative Evidence from Three Countries', Oxford Development Studies, vol. 30.

Maluccio, J.A. (2003), 'Education and Child Labor: Experimental Evidence from a Nicaraguan Conditional Cash Transfer Program’ in P.F. Orazem, G. Sedlacek and 
Z. Tzannatos (eds.; forthcoming) 'Child Labor and Education in Latin America'. Washington DC: InterAmerican Development Bank and World Bank.

Maskus, K. (1997), 'Should Core Labor Standards be Imposed Through International Trade Policy?', Policy Research Working Paper No. 1817, World Bank.

Mehrotra, S. and Biggeri, M. (2002), 'The Subterranean Child Labor Force: A Comparative Analysis of Subcontracted Home-based Manufacturing in Five Asian Countries', mimeo: UNICEF, Florence.

Moehling, C. (1999), 'State Child Labor Laws and the Decline of Child Labor', Explorations in Economic History, vol. 36.

Morduch, J. (2000), 'Sibling Rivalry in Africa', American Economic Review, vol. 90.

Myers, W. (1988), 'Alternative Services for Street Children: The Brazilian Approach', Bequele, A. and Boyden, J. (eds.), Combating Child Labor, Geneva: ILO.

Nagaraj, K. (2002), 'Female and Child Workers in a Household Industry: A Case Study of Beedi Industry in Karnataka and Tamil Nodu', mimeo: Madras Institute of Development.

Nardinelli, C. (1990), Child Labor and the Industrial Revolution, Bloomington : Indiana University Press.

Skoufias, E. and Parker, S. (2003), 'The Impact of Progressa on Child Work and Schooling' in P.F. Orazem, G. Sedlacek and Z. Tzannatos (eds.; forthcoming) 'Child Labor and Education in Latin America'. Washington DC: InterAmerican Development Bank and World Bank.

Patrinos, H.A. and Psacharopoulos, G. (1997), 'Family Size, Schooling and Child Labor in Peru', Journal of Population Economics, vol. 10.

Psacharopoulos, G. (1997), 'Child Labor versus Educational Attainment: Some Evidence from Latin America', Journal of Population Economics, vol. 10.

Ranjan, P. (1999), ‘An Economic Analysis of Child Labor', Economics Letters, vol. 64.

Ranjan, P. (2001), 'Credit Constraints and the Phenomenon of Child Labor', Journal of Development Economics, vol. 64.

Ravallion, M. and Wodon, Q. (2000), 'Does Child Labor Displace Schooling? Evidence on Behavioral Responses to an Enrollment Study', Economic Journal, vol. 110. 
Ray, R. (2000), 'Child Labor, Child Schooling and Their Interaction with Adult Labor :

Empirical Evidence for Peru and Pakistan', World Bank Economic Review, vol. 14.

Ray, R. (2000a), 'Analysis of Child Labor in Peru and Pakistan: A Comparative Study', Journal of Population Economics, vol. 13.

Razzaz, S. (2001), 'Wealth Distribution and Child Labor: Dynamic Welfare Issues', mimeo: World Bank.

Rodrik, D. (1996), 'Labor Standards in International Trade: Do they Matter and What do we Do about Them', Policy Essay No. 20, Washington, D.C.: Overseas Development Council.

Rogers, C. and Swinnerton, K. (2001), 'Inequality, Productivity, and Child Labor: Theory and Evidence', mimeo: Georgetown University.

Rosati, F.C. and Rossi, M. (2002), 'Children's Working Hours, School Enrollment and Human Capital Accumulation', mimeo : University of Rome, Tor Vergata.

Rosenzweig and Evenson (1977), 'Fertility, Schooling, and the Economic Contribution of Rural Children in India,' Econometrica, vol. 45.

Santoro, M. A. (2000), Profits and Principles: Global Capitalism and Human Rights in China, Ithaca: Cornell University Press.

Satz, D. (2002), 'Normative Dimensions of Child Labor', mimeo: Stanford University.

Schultz, T. P. (2001), 'School Subsidies for the Poor: Evaluating the Mexican Progresa Poverty Program', Yale University, Economic Growth Center Paper No. 834.

Siddiqui, K. (2001), Better Days, Better Lives: Towards a Strategy for Implementing the Convention on the Rights of the Child in Bangladesh, Dhaka University Press.

Singh, N. (2003), 'The Impact of International Labor Standards: A Survey of Economic Theory', in Basu, K., Horn, H., Roman, L., and Shapiro, J. (eds.), International Labor Standards: History, Theories and Policy, Blackwell Publishers.

Srinivasan, T. N. (1996), 'International Trade and Labor Standards from an Economic Perspective', in van Dyck, P. and Faber, G., ed. Challenges to the New World Trade Organization, Amsterdam: Kluwer.

Stahl, K. and Stalmarker, M. (2002), 'A Case Study Illustrating the Relationship Between Core Labour Standards and Trade, International Competition and its Impact on Working Conditions in the Indian Garment Export Industry,' mimeo: Goteburg University. 
Standing, G. (2001), 'Human Development', Boston Review, February, vol. 26.

Swaminathan, M. (1997), 'Do Child Workers Acquire Specialized Skills? A Case Study of Teenage Workers in Bhavnagar', Indian Journal of Labour Economics, vol. 40.

Swinnerton, K.A. and Rogers, C.A. (1999), 'The Economics of Child Labor: Comment', American Economic Review, vol. 89.

Tanaka, R. (2003), 'Inequality as a Determinant of Child Labor', mimeo: New York University.

Tuttle, C. (1999), Hard at Work in Factories and Mines: The Economics of Child Labor during the British Industrial Revolutions, Boulder, Colorado: Westview Press.

Tzannatos, Z. and Symons, J. (1989), 'An Economic Approach to Fertility in Britain since 1860', Journal of Population Economics, vol. 1989.

Tzannatos, Z. (2003), 'Child Labor and School Enrolment in Thailand in the 1990s', Economics of Education Review (forthcoming)

U.S. Department of Labor (2000), By the Sweat and Toil of Children, Vol. VI: An Economic Consideration of Child Labor, Washington: US Department of Labor, Bureau of International Labor Affairs.

Wahba, J. (2002), 'The Influence of Market Wages and Parental History on Child Labor and Schooling in Egypt', mimeo: University of Southampton.

Weiner, M. (1991), The Child and the State in India, Princeton: Princeton University Press.

Yap, Y-T., Sedlacek, G., and Orazem, P.F. (2003) 'Limiting Child Labor Through BehaviorBased Income Transfers: An Experimental Evaluation of the PETI Program in Rural Brazil' in P.F. Orazem, G. Sedlacek and Z. Tzannatos (eds.; forthcoming) 'Child Labor and Education in Latin America'. Washington DC: InterAmerican Development Bank and World Bank.

UNICEF (1995), 'Girls in Especially Difficult Circumstance: An Action Report', UNICEF, Kathmandu

Zelizer, V. A. (1985), Pricing the Priceless Child: The Changing Social Value of Children, New York: Basic Books. 
Figure 1

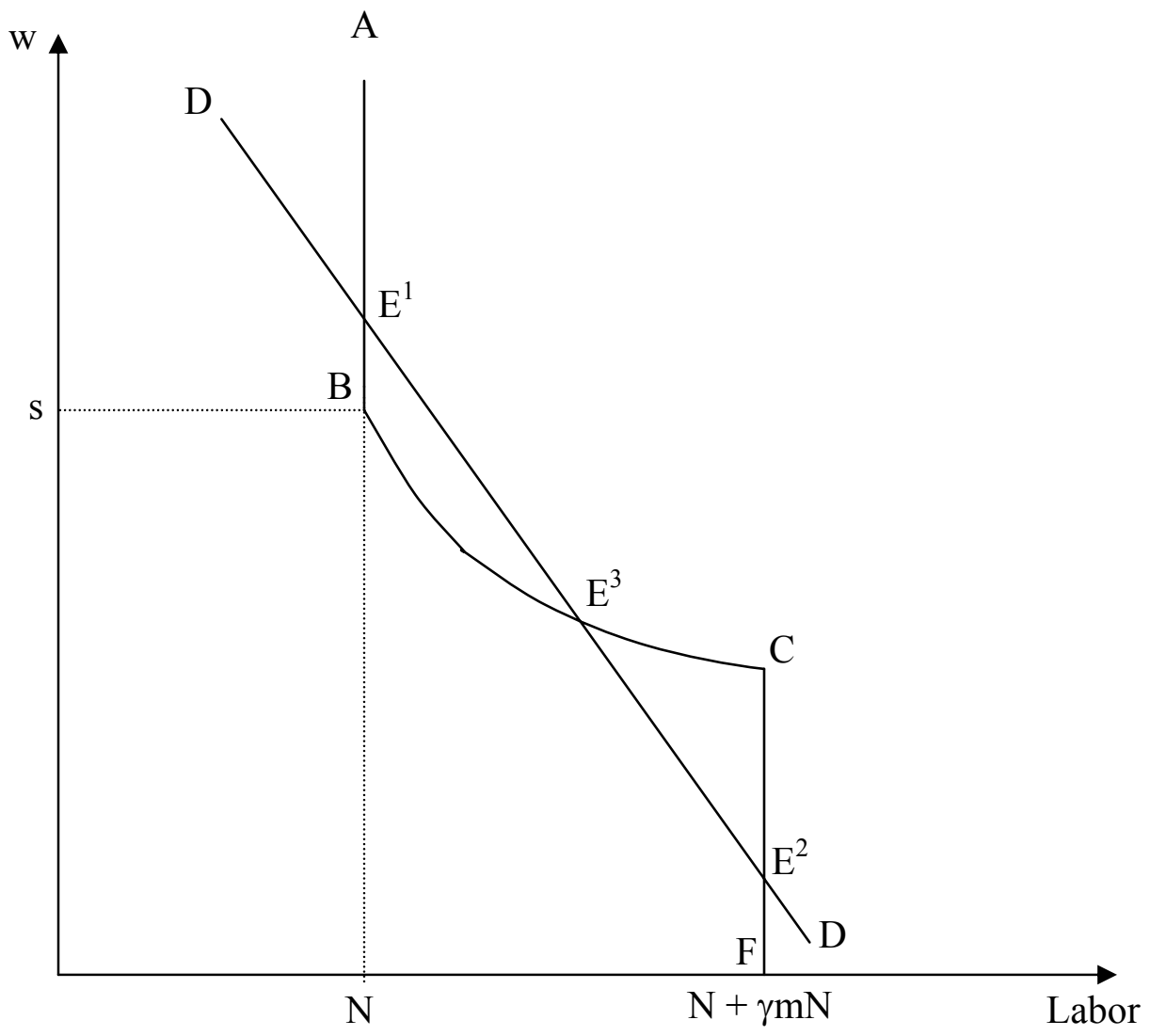

